Revue d'histoire de l'Amérique française

BEVUE D.HISTOIRE DE L'AMÉRIQUE FRANÇAISE

\title{
The Canadian Historical Review, XXXI, 2 (Toronto, June 1950): 113-124. Gerald S. GRAHAM, "The Maritime Foundations of Imperial History"
}

\section{Gordon O. Rothney}

Volume 4, numéro 2, septembre 1950

URI : https://id.erudit.org/iderudit/801648ar

DOI : https://doi.org/10.7202/801648ar

Aller au sommaire du numéro

Éditeur(s)

Institut d'histoire de l'Amérique française

ISSN

0035-2357 (imprimé)

1492-1383 (numérique)

Découvrir la revue

Citer ce compte rendu

Rothney, G. O. (1950). Compte rendu de [The Canadian Historical Review, XXXI, 2 (Toronto, June 1950): 113-124. Gerald S. GRAHAM, "The Maritime

Foundations of Imperial History"]. Revue d'histoire de l'Amérique française, 4(2),

293-293. https://doi.org/10.7202/801648ar d'utilisation que vous pouvez consulter en ligne.

https://apropos.erudit.org/fr/usagers/politique-dutilisation/ 
The Canadian Historical Review, XXXI, 2 (Toronto, June 1950): 113-124. Gerald S. Graham, "The Maritime Foundations of Imperial History".

This is an Inaugural Lecture delivered on November 22, 1949 by Gerald S. Graham, upon his appointment as Rhodes Professor of Imperial History in the University of London, England. It is a brief survey of the subject dealt with more fully in his recent Empire of the North Atlantic, ie. of the "epoch of empire", the past four centuries "when the control of the surface of the oceans was the determining influence on the foundation of great empires".

Professor Graham studies the effect of sea power upon the struggle between France and Britain in America. "The essential difference between the two countries lay in the attitudes of kings and governments, for sea power is basically an artificial creation", he says. "In comparison with continental considerations, the French overseas empire in the eighteenth century counted as little more than an important subsidiary."

Gordon O. RothNex 